\title{
TÜRK ARŞIVLERI VE ERMENI MESELESI
}

\author{
YUSUF SARINAY*
}

\section{Giriş}

Tarihin amacı; sebep sonuç ilişkisi içinde olayları belgelere dayanarak, gerçeklere mümkün olduğu kadar yaklaşarak göz önüne sermek ve değer yargısını okuyucuya bırakmaktır. Hele, yazılan tarihi olay, geçmişi olduğu kadar bugünü ve geleceği de etkiliyorsa, durum çok daha büyük bir dikkati ve objektifliği gerektirir. Bu objektiflik, tarihin temel kaynakları arasında önemli bir yere sahip olan belgelere başvurularak olușturulur. Cünkü belgeler tarihin en güvenilir şahitleridir. Bu şahitler olmadan ortaya çıkacak sonuçlara șüphe ile bakılmalıdır. "Tarih belgeyle yazılır" hükmü tüm dünya ilim camiasinca kabul edilen bir gerçektir. Uluslararası hukukta da siyasi, ekonomik, idari, kültürel ve diğer sorunlarla ilgili alınacak her türlü kararda, arşivlerin en güvenilir ve en objektif kaynaklar olduğu kabul edilmektedir. Bu sebeple geçmiş olayları incelerken arșivlere inilme zorunluluğu vardır. Çünkü arşivlere dayalı bilimsel çalıșmalar önyargı ve yanlı bilgilendirilmeden kaynaklanan taraflı siyasi yaklaşımları ortadan kaldıracaktur.

Böyle bir anlayıșla hareket eden Başbakanlık Devlet Arşivleri Genel Müdürlüğü, başta Ermeni meselesi olmak üzere, Türk arşivlerinde arașturma yapılmadan yazılacak bir bölge ve dünya tarihinin eksik kalacağının bilinciyle modern arşivciliğin ana ilkesi olan açıklık prensibini temel dayanak kabul etmiș, araşturmacılara sunulan hizmetlerde çağın gereklerine uygun yeni düzenlemeler yapmıştır. Bu çerçevede;

Başbakanlık Devlet Arșivleri Genel Müdürlüğü, başta Ermeni konusu olmak üzere birçok konuda tasnif çalışmalarını hızlandırarak, tamamlamış ve araștırmacıların hizmetine sunmuștur.

Türkiye'ye yasal yollardan girmiș yabancılar ve bunların vekilleri araștırma yapacakları arşivlere veya arșivlerin bağlı bulunduğu idareye bizzat veya posta ile müracaat edebilmektedir. Müracaat eden kişilere aynı gün 
arașturma izni verilmektedir. Müracaatlar, yurt dıșından T. C. Büyükelçilik ve başkonsoloslukları aracılığıyla da yapılabilmektedir.

Tasnif edilmiş ve son işlem tarihi üzerinden otuz (30) yıl geçmiș arşiv malzemesi hiçbir kısıtlama olmadan arașturma ve incelemeye açılmaktadır.

Araştırmacılara bir iş günü içerisinde verilen belge, defter veya dosya sayısı arturılmıştır.

Araşturmacılar, araștırma ve incelemeleri esnasında arșiv yönetiminin uygun göreceği mahallerde portatif yazı makinesi veya bilgisayar kullanabilmektedir.

Yine dünya bilim çevrelerine ve bilim adamlarına kolaylık sağlamak, bilginin paylaşılmasını ve öğrenmenin önündeki engelleri azaltmak maksadıyla internette bir web sayfası açılmış ve bilgisayar ortamında belge kataloglarımız yayınlanmıştur. Bu konudaki talep, istek vb. "http://www.devlet-arsivleri.gov.tr" adresinden temin edilebilmektedir.

Osmanlı dönemi arșiv belgelerinin mikrofilme alınması ve elektronik ortama aktarılması çalıșmaları 2002 yılında bașlatılmıș olup, İstanbul ve Ankara'da araştırma salonlarında elektronik ortamda hizmet verilmeye başlanmışur.

Bu düzenlemelerle, Türk arşivlerinin çağın gereklerine uymasını sağlayarak kolay ulașılabilir bir arşiv haline getirmek amaçlanmıștır.

Türk arşivlerinde temel ilke olarak kabul edilen açıklık prensibi doğrultusunda Ermenistan, Boston Taşnak, Rusya ve Ermeni Patrikhanesi ve bağlı kiliselerdeki arșivlerde bulunan belgelerin de açılması, konuyla ilgili çalıșmalar yapan bilim adamlarına objektif araștırma imkanı verecektir.

Bu makalede Bașbakanlık Devlet Arșivleri Genel Müdürlüğü Osmanlı Arşivi Daire Başkanlığı ve Genelkurmay ATASE Başkanlığı Arșivi’nde Ermeni konusu ile ilgili fonlar belgelerden örnekler verilerek tanıtulacaktır.

\section{Ermeni Meselesi Hakkında Osmanlı Arşivleri'nde Bulunan Fonlar}

Osmanlı Arşivlerinde genel olarak Ermenilerle ilgili bir çok fonda belge bulunmaktadır. Ermeni sorunu ve tehcir uygulaması ile ilgili aşağıda kısaca bu fonlarla ilgili tanıtıcı bilgiler verilecektir ${ }^{1}$. Ermenilerle ilgili arșiv kayıtlanı

\footnotetext{
${ }^{1}$ Osmanlı Arşivindeki belge tasnifleri ve katalog bilgileri için ayrıca bkz. Başbakanlık Osmanlı Arșivi Rehberi, İstanbul, 2000.
} 
sadece belgelerden ibaret değildir. Osmanlı bürokrasisinin Tanzimat öncesi kayıtları defter kayıtları şeklindedir. Defterler; Osmanlı bürokrasisinde alınan kararların, hükme bağlanan konuların kaydolunduğu serîlerdir. Bu sebeple öncelikle defter fonlarından bahsedilecektir.

\section{1- Defter Fonlan}

Tanzimat öncesi Osmanlı merkez teșkilau dönemine ait defterler, iki ana serî hâlinde günümüze intikal etmiștir. Birincisi: Devletin siyasî ve hukukî kararları ile beldelerin asayiș ve nizamına dair hükümlerin kaleme alındığı Divân-ı Hümayûn Defterleri'dir. İkincisi ise sadece malî konularda mirî işlerden sayılan cizye, avârız ve mukataa işleriyle ilgili konuların düzenlenip kaydolunduğu Maliye Defterleri'dir.

Burada sadece Ermenilerle ilgili kayıtların bulunduğu defterler hakkında ana hatlarıyla bilgiler verdikten sonra, defterlerdeki kayıtlardan örnekler verilecektir.

\section{a- Mühimme Defterleri}

Divân-1 Hümayûn toplantılarında müzâkere edilen iç ve dış meselelere ait siyasî, askerî, içtimaî ve iktisadî kararların kaydedildiği bu defterlere "Mühimme Defterleri" adı verilmiştir. Osmanlı Arşivi'nde 419 adet Mühimme Defteri mevcuttur.

XVI. yüzyılın ortalarından XX. yüzyılın ilk yıllarına ulaşan bir dönem içinde, küçük zaman bölümleri hariç ortalama 350 yıllık zaman dilimi itibarıyla, hiçbir doğu ve batı devletinde bulunmayan kültür ve tarih zenginliğini ihtiva eden Mühimme Defterleri, Osmanlı Arşivi defter serîleri içinde şüphesiz önemli yer tutar. Ana konularını; devleti ilgilendiren siyasî, iktisadî, kültürel, sosyal ve harp tarihine dair üst düzey kararlar teşkil eder. Bugünkü anlamda düşünülecek olursa, Bakanlar Kurulu kararlarına benzemektedir. Mühimme defterlerinde Ermenilerin siyasî, iktisadî, kültürel, sosyal sahalardaki faaliyetleriyle ilgili bir çok kayıt vardır. Așağıda bununla ilgili birkaç Mühimme defterlerinden hüküm örneği alınmıştur.

Bursa kadısına: Bursa'da iki Ermeni kilisesine dahleden Fiș Acem'in müdahalesinin men'i hakkında ${ }^{2}$ gönderilen hüküm.

${ }^{2}$ BOA., Mühimme Defteri, No: 3/1082. 
Sulumanastur'daki Ermeni kilisesi keşișleri eski keșişhanelerinin yanma bir keşişhane daha yapıp burada içkili, sazlı-sözlü âlem yapıp Abdi Çelebi Mescidi cemaatini ve Müslümanları rahatsız ettikleri yolundaki șikâyetin tahkikiyle sonradan yapılan keşişhanenin yıkılıp eski keşişhanede de alem yapturılmamasi ${ }^{3}$ hakkında hüküm.

Yahudi, Ermeni ve diğer gayri müslim halkın kendileri için belirlenen ve zikrolunan özelliklere sahip kıyafetleri giymeleri; kıymetli giysiler giymekten kaçınmaları ${ }^{4}$ hakkında hüküm.

İstanbul'da bulunan Ermenilerin, mezarlıklarının yanında Sultan Bâyezîd Evkafi'na ait olan bir tarlanın, karşılığında bir akar vermek şartıyla kendilerine mezarlık olarak verilmesi yolundaki taleplerinin mütevelli tarafından incelenmesi ve vakfa faydalı ise arz edilmesi ${ }^{5}$ hakkında hüküm.

İstanbul'da sakin, Sultan Mehmed Evkâfı reâyasından olan Ermenilerin, kilisede toplandıklarında, içlerindeki düșkün ve yardıma muhtaç olanlara verilmek üzere gönüllü olarak kendi aralarında topladıkları paraya ve kiliselerinin bahçesindeki meyvelere, patrikleri olan Sakarya tarafından, yanına toplanan bazı papazların yönlendirmesiyle, âdet ve kanuna aykırı olarak fazladan para talep edilmek suretiyle yapıldığı bildirilen müdahalenin engellenmesi' hakkında hüküm.

Revan'a tâbi Üçkilise civarmuaki Ermenilerin katogikosu olup, patrikliğe bağlı hususlarda Ermeniler kendine müracaat etmekteler iken, bazı unsurların bölgeye gelmesi üzerine Osmanlı ülkesine yerleşmiș olan Sahak'a diğer murahhasa, papaz ve keșișlerin müdahale ettirilmemesi ${ }^{7}$ hakkında hüküm.

Fatih Sultan Mehmed Han Evkâfı reâyasından olan İstanbul'da Sulumanasur Cemaati Ermenilerinin toplant günlerinde bağışlarıyla biriktirilen veya ihtiyaç fazlası bal mumunun satılmasıyla elde edilen ve kiliseye harcanan paradan kendileri için akça talep ettikleri bildirilen Patrik Zakarya ile Avanos, Kirkoz ve Serkiz adlı papazlara engel olunması ${ }^{8}$ hakkında hüküm.

\footnotetext{
${ }^{3}$ BOA., Mühimme Defteri, No: 6/1200.

'BOA., Mühimme Defteri, No: 7/1989.

5 BOA., Mühimme Defteri, No: 85/82/7.

${ }^{4}$ BOA., Mühimme Defteri, No: $85 / 67$.

${ }^{7}$ BOA., Mühimme Defteri, No: $85 / 87$.

${ }^{8}$ BOA., Mühimme Defteri, No: 85/101.
} 
İstanbul etrafında tereke ziraati yapan reâyanın, terekelerini biçip kaldırmalarından sonra, bazı Ermenilerin tarlalarında kalan anızı yolup zarar vermelerine engel olunması" hakkında hüküm.

Bursa'da, Karaağaç denilen mevkide iki cami arasına Ermeniler tarafından sonradan yapıldığı ve Müslümanların ibadetine mâni olduğu bildirilen kilisenin bilirkișilerden soruşturulmak suretiyle keșfinin yapılması; durum bildirildiği gibi ise yıkılmass ${ }^{10}$ hakkında hüküm.

\section{b- Tahrir Defterleri}

Osmanlılar, bir yeri fethettiklerinde o bölgeye yetkili bir emin (il yazıcıları) gönderip nüfus ve gelir kaynaklarını ayrıntlarıla araşurıp deftere geçirirler, böylece her sancak için ayrı bir nüfus ve gelir defteri meydana getirilirdi. $O$ bölgede vergi kaynakları çeşitli etkenlerle değiştiği zaman, her 1020-30 ylda bu tahrir ișlemi yenilenirdi.

Tahrir defterleri, Osmanlı İmparatorluğu'na dahil memleketlerin sosyal, demografik ve ekonomik tarihine ait, benzeri başka hiç bir yerde bulunmayan mufassal istatistik kaynaklandır.

Tahrir devletleri sayesinde, altu yüz yıl boyunca Osmanlı idaresi altunda yaşayan Ermenilere karşı, Osmanlı Devleti'nin izlediği politikaların ana hatlarını, Ermenilerden ve diğer unsurlardan alınan vergileri, onların yașadıkları bölgeleri, nüfus hareketlerini incelememiz mümkündür. Buna örnek olması amacıyla Mardin Livasıyla Diyarbakır eyaletinin tahrir kayıtlarını özetle aşağıya kaydediyoruz.

Mardin livasında 1.848 hane ve 772 bekâr Ermeni, 6.718 hane ve 1.378 mücerred Müslüman nüfus kaydedilmiștir ${ }^{11}$.

Diyarbakır eyaletinin genelinde ise 11.772 hane ve 3.225 bekâr Ermeni kaydedilmiștir. Eyâlette 66.732 hane ve 15.661 bekâr da Müslüman nüfus $\operatorname{vardur}^{12}$.

Mufassal tahrir defterlerinde şahısların isimlerini, statülerine göre verdikleri vergileri ayrıntılı bir șekilde görmek mümkündür.

\footnotetext{
BOA., Mühimme Defteri, No: $85 / 497$.

${ }^{10}$ BOA., Mühimme Defteri, No: $85 / 704$.

${ }^{11}$ BOA., Tapu Tahrir Defteri, No: 998 , s. 37.

${ }^{12}$ BOA., Tapu Tahrir Defteri, No: 998, s. 279
} 


\section{c- Gayr-i Müslim Cemâatlere Ait Defterler}

Divân-1 Hümayûn tarafindan tutulan bu defterler, gayr-i müslimlerle ilgili konularla, gayr-i müslim cemâatin her türlü hak, imtiyaz ve muâmelatuna ait hükümleri ihtiva etmektedir. Papazlara verilen beratlar da bu kalemde hazırlanmıștur. Gayr-i Müslim Cemâat Defterleri, Evâmir-i Maliye Kalemi'ne bağlı olup, 1837 senesinde Piskopos Halifeliği'nin Divân-ı Hümayûn'a bağlanması üzerine Divân-ı Hümayûn tarafından tutulmuștur.

Bu defterler arasında bulunan Şurût-1 Milel-i Muhtelife Defterleri; muhtelif Hıristiyan cemâatlerinin bağlı bulundukları mezheplerin patrik ve metropolitlerine ait hükümleri muhtevîdir. Bu hükümlerde ruhanî reislerinin vazife ve selâhiyetleri ile gerek devlet ve gerekse cemâatleriyle olan münasebetleri tayin ve tasrîh edilmiştir. Defterlerde șu ruhanî reislere ait hükümler vardır:

İstanbul Rum Patrikliği ve buna bağlı metropolidler, Kudüs Rum Patrikliği, Antakya Rum Patrikliği ve buna tâbi metropolidler, Kıbrıs Bașpiskoposluğu'na tâbi piskoposlar, Mısır ve İskenderiye Patrikliği, Tûr-1 Sina Keșişleri, Efrenc (Fransız) Piskoposluğu, İstanbul ve tevâbii Ermeni Patrikliği ve buna bağlı murahhaslıklar, Kudüs Ermeni Patrikliği, Üç Kilise Katogikosluğu, Çanlı Kilise Murahhashı̆̆, Atina ve Sis Murahhaslığı, Nasturi Murahhaslığı, Yahudi ve Süryani Patrikliği, Ermeni ve Katolik Patrikliklerinin tashih olunan beratları.

989 numaralı "Divân-ı Hümayûn Defterleri Kataloğu"nda kayıtı H. 1236-1337/M. 1820-1918 tarihleri arasında gayr-i müslimlerle ilgili konuları ihtiva eden, toplam 18 adet defter mevcuttur. Bunlardan 4'ü Ermenilerle ilgilidir. Gayr-i Müslim Cemaatlere Ait Defterler'de Ermenileri ilgilendiren hükümlerden üçü özet, alı örnek belge aşağıda yer almaktadır.

1- Konya'da yaşayayan Ermenilerin özel ve genel dini görevleri Ankara Murahhasalığı tarafindan görülüp idare olunmakta ise de mesafenin uzaklığı ve Konya'nın önemine binaen orada bir murahhasalık teșkiliyle Rahib Şirinyan Efendi'nin vekâleten tayini hakkında irade ${ }^{13}$.

2- Ermeni Patrikhanesi Umum Ruhani Meclisi'nde kararlașturılıp Patriklikten gönderilen yazı üzerine; Osmanlı Devleti'nin hiçbir yerinde dini müesseselerin, yani kilise inșası ve tamiri, okul inșası ve tamiri gibi konularda

${ }^{13}$ BOA. Gayr-i Müslim Cemaatlere Ait Defterler, No: 9 , s. 1. 
ahalinin isteklerinin Patrikhaneye sorulmadan işlem yapılmaması hakkında Meclis-i Mahsus-1 Vükelâ karar1 ${ }^{14}$.

3- Behisni ahalisinden Kirkor ve Agop ağalar vefat eden Sis katogikosuna mirasçı olmaları sebebiyle verdikleri dilekçe üzerine yapılan araştırma sonucu emlak ve arazilerinin aile fertlerine taksimiyle kilisedeki mal ve eşyalarının kendisinden sonraki katogikosa devredilmesi ${ }^{15}$.

4- Palu ve Gevar manastırı ve bağlı kiliseler delegesi Mıgırdıç Rahib'in görevden alınması üzerine yerine Serkiz rahibinin patrikhanece atandığı (24 Ekim 1862) ${ }^{16}$.

5- Deniz Kuvvetleri generallerinden Kocaeli Sancağı Mutasarrıfi Mașuk Pașa ve kaza naibine gönderilen bir hükümle, Ermeni Patrikliğine bağh İzmit ve Ermișe (Akmeșe) rahibinin vefat üzerine ehliyeti kanıtlanan Abram Rahib'in yine Ermeni patriği tarafından atandığı ve rahibin özlük ve dini haklarına hiç kimsenin müdahale etmemesi hakkında 25 Eylül 1871 tarihinde Padișah tarafindan çıkarılan ferman ${ }^{17}$.

6- Bayburt ve bağlı kilise kuruluşlan Delegesi Haçadoryan Aristakis Efendi'nin istifası üzerine bu göreve Rahib Abranosyan Kigork Efendi'nin Ermeni Patrikhanesi tarafından atandığı bildirilerek Haçadoryan Aristakis'in özlük ve dini görev ve haklarına hiç kimsenin müdahale etmemesi hakkında 21 Haziran 1904'te çıkarılan Padișah Fermanı ${ }^{18}$.

Tanzimat öncesi Osmanlı merkez teșkilatı dönemine ait defterlerle ilgili bu bilgilerden sonra, şimdi, Ermeni meselesi ve tehcir uygulaması ile ilgili belgelerin bulunduğu fonlarla ilgili kısa bir tanıtıcı bilgiye geçiyoruz ${ }^{19}$.

\section{Belge Fonları}

\section{a) Hariciye Nezareti Belgeleri}

Hariciye Nezareti Arşivi'nde, siyasî, hukukî, idarî konulardaki çok önemli meselelerin yanısıra, ticaret anlașmalan’; sefâret ve șehbenderliklerle

${ }^{11}$ BOA. Gayr-i Müslim Cemaatlere Ait Defterler, No: 9, s. 3.

${ }^{15}$ BOA. Gayr-i Müslim Cemaatlere Ait Defterler, No: 9, s. 3.

${ }^{16}$ BOA. Gayr-i Müslim Cemaatlere Ait Defterler, No: 8, s. 15.

${ }^{17}$ BOA. Gayr-i Müslim Cemaatlere Ait Defterler, No: 8, s. 20.

${ }^{18}$ BOA. Gayr-i Müslim Cemaatlere Ait Defterler, No: 8, s. 34.

${ }^{19}$ Osmanlı Arşivindeki belge tasnifleri ve katalog bilgileri için ayrıca bkz. Başbakanlık Osmanh Arșivi Rehberi, İstanbul, 2000. 
yapılan yazışmalar; köle ticaretinin men'i; Sırbistan'daki Müslüman halkın dinî meseleleri; yabancı devlet bașkanlarına gönderilen ve onlardan gelen, daha çok doğum, vefat, cülûs, evlilik konularındaki nâmeler; rütbe, nişan ve madalya tevcihleri; smırların dışında kalan topraklara ait tapu tahkikleri yer alır. Başlıca fonları șunlardır. Siyasi Kalemi Belgeleri (HR.SYS.), Mektubî Kalemi Belgeleri (HR.MKT.), Hukuk Müșavirliği İștișare Odası Belgeleri (HR.HMȘ.ISO.), Hukuk Kısmı Belgeleri (HR.H.), Mütenevvia Kısmı Belgeleri (HR.MTV.).

Hariciye Nezareti belgeleri arasında Ermeni meselesiyle ilgili binlerce vesika vardır. Yabancı ülkelerdeki Ermenilerin faaliyetleri (İngiltere ${ }^{20}$, Fransa $^{21}$, Rusya ${ }^{22}$, Amerika ${ }^{23}$, Almanya ${ }^{24}$, İtalya, Bulgaristan ${ }^{25}$, Romanya, Yunanistan), Osmanlı sınırları içinde bulunan Ermenilerin durumları, Ermenilerin İstanbul'da çıkardıkları karışıklıklar (Kumkapı olayı ${ }^{26}$, Babıali gösterisi, Osmanlı Bankası baskını ${ }^{27}$ ), Anadolu'da meydana gelen Ermeni olayları ${\text { (Erzurum olaylar1 }{ }^{28} \text {, } \text { Yozgat }^{29} \text {, Merzifon }}^{30}$, Kayseri olaylar1 ${ }^{31}$, Bitlis olaylari ${ }^{32}$, Van isyanı, Sason-Taluri isyanı, Maraș ve Zeytun'da çıkan isyanlar, Sivas olayları, Tokat olayları, Diyarbakır'da çıkan olaylar, Mamuratülaziz ve Arapkir olayları, Harput'ta çıkan olaylar, Trabzon olayları, Eğin hadiseleri, Üç büyük devlet tarafindan Ermenilerin de yaşadıłlan vilayetlerde islahat yapılması istekleri $^{33}$, Ermeni komitelerinin faaliyetleri, Ermenilerin Osmanlı ülkesine silah sokma teşebbüsleri, Ermenilerle ilgili olarak yabancı matbuatta çıkan yazılar $^{34}$, Birinci Dünya Savaşı sırasında Ermeni faaliyetleri ${ }^{35}$, Ermeni tehciri $^{3{ }^{3 i}}$, Ermenilerin Doğu Anadolu'da Müslüman halka yapukları mezalim ${ }^{37}$

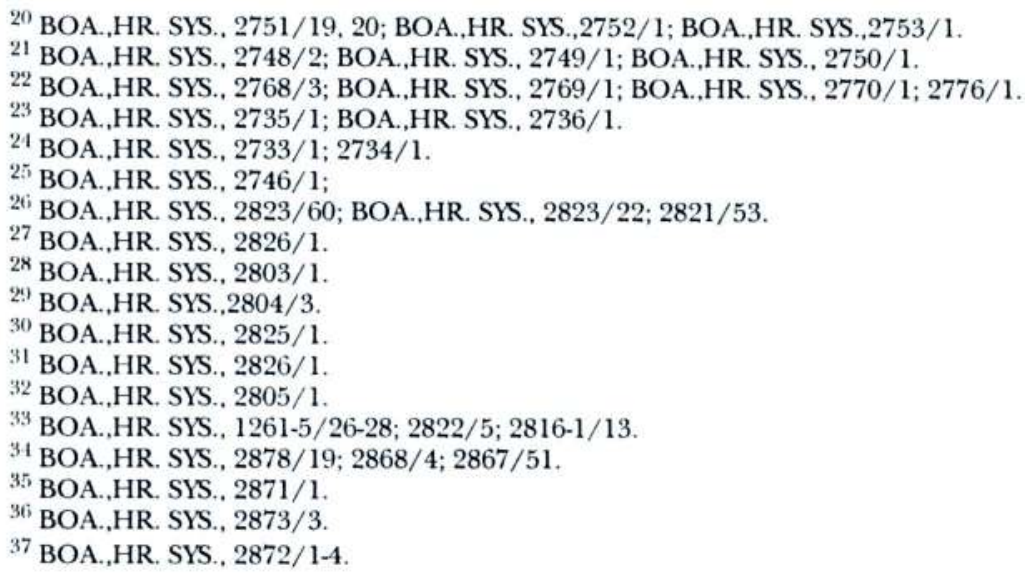


bu fondaki belli başlı konu başlıklarıdır. Bunlardan bașka fonda Ermenilerle ilgili konu başlığı olabilecek nitelikte bir çok belge vardır.

b) Dahiliye Nezareti Belgeleri (DH.)

Kalem-i Mahsûs Müdüriyeti Belgeleri (DH.KMS.); Kalem-i Mahsûs Müdüriyeti ile ilgili belgelerin muhtevası şu şekildedir: İtilâf Devletleri'nin işgal hareketleri, Kuvâ-yı Milliye faaliyetleri, Yunan işgali ve mezâlimi, Çetecilik faaliyetleri, Memur tayin ve azilleri, Madalya i'tası ile muhtelif konular.

Siyasî Kısım Belgeleri (DH.SYS.); Dahiliye Nezareti'nin siyasî işlerine bakan müstakil bir kalemi yoktu. Katalogları araștırmaya sumulan siyasî vesikalar; Dahiliye Nezareti'nin müstakil kalemi olmayıp, Muhaberât-ı Umumiye Dairesi'nin evrak memurlarınca konularına göre siyasî, hukuk, idarî ve mütenevvia diye ayrılarak siyasîler bir araya getirilmiş ve üzerlerine orijinal karton ve dosya numaraları verilmiş olanlarıdır.

Şifre Kalemi Belgeleri (DH.ŞFR.); Dahiliye Nezareti'ne bağlı kalemler arasında yer alan Şifre Kalemi'nin müstakil bir kalem olarak teşkilat içerisinde yer alması 1914 yıllarına rastlar. Bilhassa Osmanlı Devleti yönetiminin taşra birimleri ile âcil yaptığı muhâberatta, telgraf ile haberleşmenin ve bu usûlün devlet muhâberatına girmesiyle "Şifre Kalemi"nin önemi de artmıştur. Şifre Kalemi'nin, umumiyetle Dahiliye Nezareti'nin ve ona bağlı alt birimlerin diğer vilayetler ve mutasarrıflıklar ile yaptığı muhâberatta aracı olduğu anlaşılmaktadır. Ancak, bu çalışmaların yanında bazen diğer nezaret ve devlet dairelerinin acele ve gizli muhaberâtının șifrelendiği bir aracı büro durumunda da bulunmaktadır.

Mütenevvia Kısmı Belgeleri (DH.MTV.); Mütenevvia tasnifi içerisinde yer alan belgeler hemen her türlü konuyu ihtiva etmektedir. Ancak ağırlık itibari ile şu konulara rastlanmaktadır. Tabî̀ afetler ve yapılan yardımlar; memurların tayin, azl, izin, muhakeme vs. meseleleri; tensikat; arazi davaları; madalya, nişan verilmesi ve diğer taltifler; Hicaz demiryolu; iltica haberleri; yabancı seyyahlara tanman kolaylıklar.

Asayiş Kalemi Belgeleri (DH.EUM.AYŞ.); Bu fonda bulunan belgeler genel olarak şu konuları ihtiva etmektedir: Şekâvet ve çeteler; katil, yaralama, hırsızlık ve tecavüz olayları; cerâim istatistik cetvelleri ve vukuat raporları; cemiyetlerin faaliyetleri ve bunlarm takibi; işgal kuvvetlerinin kontrolü ve bu 
işgal kuvvetlerinin halka karşı muameleleri ile jandarma kuvvetlerine ve resmî görevlilere yönelik kötü muamelelerinin takibi; jandarma kuvvetleri muamelâtı (komutan tayinleri vs.); Kuvâ-yı Milliye'nin faaliyetleri; düşman donanmalarının faaliyetleri; Anadolu'nun muhtelif yerlerinde Rumlar ve Ermenilerin Müslüman halka tecavüzleri.

İdarî Kısım Belgeleri (DH.İD.); Dahiliye Nezareti İdare Evrakı bir çok değişik konuları ihtiva etmektedir. Bunlardan; mülkî taksimattaki düzenlemeler, belediye meclisleri ile idare meclisleri azalarının seçimi, gayr-i müslim ve ecnebilere ait mektepler ile kilise inșalarına ruhsat verilmesi, Osmanlı topraklarında çeşitli arkeolojik kazılara müsaade edilmesi ve eski eser kaçakçılı̆̆ını önlenmesi gibi değişik konuları zikredebiliriz.

Hukuk Kısmı Belgeleri (DH.H.); Hukuk bölümündeki vesikaların ekseriyeti, inzibatî vakalara aittir. Ayrıca, bu bölümde kamu ve șahıs hukukunun korunması için Dahiliye Nezareti ile taşra teşkilatı ve mahallî idâreler arasındaki yazıșmalarla ilgili vesikalar da mevcuttur.

İdâre-i Umumiye Belgeleri (DH.İUM.); Bu fon içinde; memurların tâyin, azl ve taltifleri; emlâk ve arazi iṣleri; zehâir ve iâșelerin toplanarak sevkedilmeleri; askeriyenin ihtiyaçlarının karșılanması; eğitim ve öğretim; vakıflar, köy, nahiye ve kaza teşkilleri; askere alma işlemleri ve seferberlik; işgal altunda kalma; deprem, yangın, sel felâketi gibi durumlarda gerekli muamele icrâsı ile dârü'l-eytâm vesair konulara rastlamak mümkündür.

Emniyet-i Umumiye Müdüriyeti Belgeleri (DH.EUM.); Asayiş ve güvenliğe ait konuların çeşitliliğinin yanı sıra polislerle ilgili işlemlerin (özlük hakları, tayin, terfi, ceza, emeklilik vs.) yürütülmesi de görev alanına girdiğinden Emniyet-i Umumiye Müdüriyeti bünyesinde muhtelif şubeler kurulmuştur.

Dahiliye Nezareti belgeleri içinde Ermeni meselesiyle doğrudan veya dolaylı olarak ilgili bulunan binlerce belge bulunmaktadır. Bu belgelerin muhtevalarından bir kısmı aşağıya çıkarılmıștır. Fakat bu muhtevaların dışında da bir çok belge mevcuttur.

Doğu Anadolu'da ıslahat yapılması ve buraya iki Avrupalı müfettiş-i umuminin tayin edilmesi çalıșmaları ${ }^{38}$, Ermeni komitelerinin Ermeni kilise- 
lerinde çıkardıkları olaylar ${ }^{3 !}$, Tehcirin sebepleri ve alınan tedbirler ${ }^{10}$, Tehcirin uygulandığı bölgeler", Ermeni sevkiyatımın yapıldığı yerler ${ }^{42}$, sevkiyata tabi tutulmayan Ermeniler ${ }^{13}$, sevkiyat için para tahsisi, Tehcire tabi tutulan Ermenilerin iaşe ve iskan masrafları ${ }^{14}$, sevkiyatın durdurulması ${ }^{45}$, Geri dönmek isteyen Ermenilere izin verilmesi ${ }^{t 6}$, ihtida eden Ermeniler ve Ermeni yetimlerinin durumu, sevk edilen Ermenilerin miktarı, Ermenilerin Müslümanlara saldırısı, Ermeni tehciri esnasındaki su-i istimallerden dolayı yapılan tutuklamalar, Adana ve mülhakatında bulunan Fransız işgal kuvvetlerine mensup Ermenilerin Türklere yaptıkları saldırılar, Paris Sulh Konferansı'nda Yunan Başvekili Venizelos ile Ermeni Murahhası arasında alınan karar üzerine Rumlarm İstanbul'u, Ermenilerin de Trabzon'u ilhak çabaları ${ }^{17}$, Tehcir sonrası memleketlerine dönen Ermeniler ${ }^{48}$, Dersaadet'te bulunan Ermenistan Hükümeti temsilcilerinin girişimleri" ${ }^{49}$, Elviye-i Selase dahilinde Ermeni ve Rumların bölgedeki Müslüman ahaliyi yok etme gayesiyle giriştikleri umumi katliam ve zulümler ${ }^{50}$, Nasturi ve Ermenilerden mürekkep İngiliz kuvvetleriyle Barzan ve Zibar aşiretleri arasındaki çatışmalar ${ }^{51}$, Mütarekeden sonra Ermeniler tarafindan kaçırılan MüslümanTürk çocuklarının ve kadınlarının hristiyanlaştırılması çabaları ${ }^{52}$, dönen Ermeni muhacirlerin iaşe ve ihtiyaçlarımın temininde yardımcı olunması, İngilizlerin Ermenilerle müştereken sınıra tecavüz etmeleri, Ingiliz tayyarelerinin köyleri bombalaması, Ermenilerin türbeleri tahrip etmesi ${ }^{53}$, Van Ermeni Taşnaksütyun Cemiyeti'nin faaliyetleri" ${ }^{51}$, Zeytun'da mukim Ermenilerin durumu, burada çıkan hadiseler ve Ermenice çıkan gazetelerin neşriyatı ${ }^{55}$,

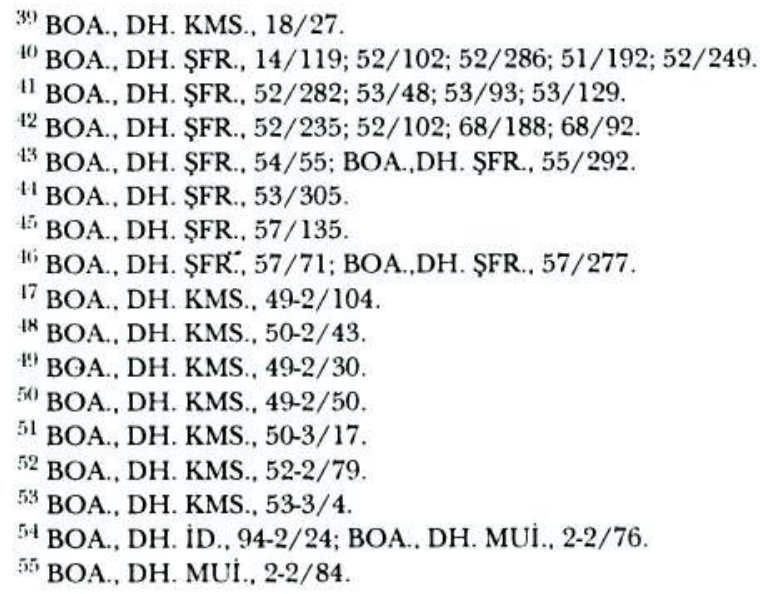


tahrip olan Ermeni ve Protestan kiliseleriyle bazı kabir ve sandukalarn tamiri masraflarmm ödenmesi, Ermeni okul, kilise gibi kurumlarmmn inșası için ruhsat verilmesi, Amerika'ya gös eden Ermeniler ${ }^{5 i}$, Fransız rahiplerinin Adana, Maraș ve mülhakattaki Ermenileri Katolik Mezhebi'ne sokmaya çalışmaları ve buna engel olunması ${ }^{177}$ gibi konular yer almaktadır.

\section{c) Ylldız Sarayı Arşivi Belgeleri}

II. Abdülhamid devrinde (1876-1909) Yildız Sarayı'nda biriken defter, belge ve gazetelerden olışan fondur. Bu fonda, II. Abdülhamid'in özel olarak ilgilendiği konular, Sadaret'ten Saray'a sumulmuş, ancak irâdeleri sâdır olmamış tezkireler, şahısların Yıldız Sarayı'na sundukları çeșitli arìza, rapor ve ihbarlar, Kâmil Paşa, Cevdet Paşa, Namık Kemal, Midhat Paşa vb. önemli şahsiyetlerin metrukâtı, dış basında Devlet-i Aliyye ile ilgili çıkan yazılar, albüm ve resimler, kanun ve nizamnâme suretleri, Abdülhanid'e ait hususî el defterleri ve cüzdanlar ile haritalar bulunmaktadır.

Devletlerarası ilişkiler, Şarkî Rumeli, Ermeni ve Mısır meseleleri, Girit hadisesi, sını olayları gibi önemli devlet problemlerinden zaptiye jurnallerinde geçen adî vukuata kadar bu dönemin çeșitli özelliklerini yansıtan bir fondur.

Ermeni meselesiyle ilgili olarak Yıldız belgelerinde beș binin üzerinde belge vardır. Bunlarm büyük bir kısmı așağıdaki fonlara dağılmıștur. Yıldız Esas Evrakı (Y.E.E.), Sadrazam Kâmil Pașa Evrakı (Yıldız Esas Evrakına Ek), Sadaret Resmî Maruzat Evrakı (Y.A.RES.), Sadaret Hususî Maruzat Evrakı (Y.A.HUS.), Mütenevvî Maruzat Evrakı (Y.MTV.), Yıldız Perâkende Evrakı.

Yıldız Arşivi fonlarıncla Ermeni meselesiyle ilgili bulunan belgelerin muhtevaları ana hatlarıyla așağıya çıkarılmışır.

Ermeniler arasında meydana gelen olaylar, Ermenilere okul ve kilise inşası için verilen müsaadeler, Anadolu'da meydana gelen Ermeni olayları, (Musa Bey olayi ${ }^{5,}$, Sason hadisesi ${ }^{59}$, Van olaylar1 ${ }^{(i)}$, Erzurum olaylari ${ }^{(i)}$ ), Ermeni Patrikhanesiyle ilişkiler, Yabancı basında çıan yazıların tercümeleri,

Biti BOA., DH. MUI., 8-3/12.

57 BOA., A. MKT. MHM., 651/17; BOA., A. MKT. MHM., 651/10.

iN BOA., YEE., 34/8; BOA., YEE., 34/9; BOA., YEE., 34/11; BOA., YEE., 34/15; Y. PRK AZJ., 16/20.

54 BOA., YEE., 4/47; BOA., YEE., 5/54; BOA., YEE., 5/133; BOA., YEE., 5/134.

(6) BOA., YEE., 5/144; BOA. YEE., 50/44; BOA., YEE., 50/47; BOA., YEE.,50/50; BOA., YEE., 50/51.

(i) BOA., Y.MTV., 260/42. 
İngiltere, Fransa, Rusya ve Amerika'da Ermeni faaliyetleri ve bu ülke devlet adamlarınm Ermenilerle münasebetleri, Ermeni nüfusu, Anadolu sslahatı için İngiltere, Fransa ve Rusya'nın ortak teșebbüsleri ${ }^{i 2}$, Hunçak ve Tașnak komitelerinin faaliyetleri, çıkardıkları olaylar ${ }^{63}$, Ermeni katogikoslukları hakkında bilgiler ${ }^{61}$, Ermeni Patrikhanesinin faaliyetleri, misyoner faaliyetleri ${ }^{65}$, Ermenilerin Bulgaristan ve Romanya'daki faaliyetleri ve oralardaki komitecilerle işbirliği, Ermenilerin yabancı ülkelere göçleri, Rusya'dan silahlı Ermeni komitecilerinin Osmanlı sınırlarına tecavüz etmeleri gibi konular vardır.

\section{d) Bâb-1 Âlî Bünyesindeki Dairelere Ait Belgeler}

Meclis-i Vükelâ Mazbataları (MV.): Meclis-i Vükelâ; sadrazamın riyâseti altunda şseyhülislâm ile nâzırlardan mürekkep olan ve devletin iç ve dış siyasetinde ve mühim işlere müteallik hususlar hakkında karar veren meclisin adıdır. Bu meclise, "Meclis-i Has" veya "Meclis-i Hass-ı Vükelâ" da denirdi ki bugünkü mânâda "Bakanlar Kurulu" demektir. 1908 Temmuz inkılâbı üzerine kurulan Meșrutiyet rejiminde bu meclis, görevlerinden dolayı padișaha ve Mebûsân Meclisi'ne karşı müșterek bir mesuliyet altuna sokulmuştur.

Meclis-i Vükelâ Mazbataları arasında Emenilerle ilgili olarak üç yüz civarında belge vardır. Bu belgeler ana hatlarıyla; Yabancı memleketlere firar eden Ermenilerden Dersaadet'e avdet edenlere memleketlerine sevk edilinceye kadar yardım edilmesi ${ }^{6 i}$, Rusya'ya göç eden Ermenilerin tekrar geri dönme talepleri ${ }^{67}$, Anadolu sslahatı konusunda bir heyet teşkil edilmesi ${ }^{i \mathrm{is}}$, Ermeni Taşnak Komitesi'nin ihtilal ve isyanı teșvik eden mensupları hakkında kanunî takibat icrası ${ }^{6 !}$, Cemaat mektebleriyle askerlik hizmeti hakkında Rum, Ermeni ve Ermeni Katolik Patrikhaneleri ile Bulgar Eksarhlığı'ndan daha sonra da Rum Melkit, Katolik ve Keldani Patrik vekaletlerinin başvuruları üzerine tanzim olunan nizamname ${ }^{70}$, Doğu Anadolu Bölgesi'nde Kürtler ve Ermeniler arasında cereyan eden cinayet ve arazi da-

${ }^{12}$ BOA., YEE., 4/10; BOA., YEE., 5/95; BOA., YEE., 11/8; BOA., YEE., 83/48.

63 BOA., YA. HUS., 498/141; BOA., YA. HUS., 501/65; BOA., YA. HUS., 502/114; BOA., YA. HUS., 518/78; BOA., Y. MTV., 237/67; BOA., YEE., 95/52.

(i) BOA., YA. HUS., 517/163; BOA., YEE., 35/103; BOA., Y. MTV., 259/101; BOA., Y. MTV., 260/61

(5) BOA., Y. MTV., 299/160; BOA., Y. PRK. AZJ., 26/80; BOA., Y. PRK. HR., 18/47; BOA., Y. PRK. BŞK., 34/28.

rit BOA., MV. 125/53; BOA., MV. 120/66; BOA., MV.136/20.

${ }^{17}$ BOA., MV.103/70; BOA., MV.95/87; BOA., MV.113/20; BOA., MV.114/76.

tis BOA., MV.123/38.

69 BOA., MV.128/68,

${ }^{70}$ BOA., MV.158/22. 
valarıyla ilgili şikayetler ve alınan tedbirler ${ }^{71}$, Harp bölgelerine yakın yerlerde bulunan Ermenilerin düșmanla ișbirliği faaliyetlerine girişip Osmanlı Ordusu'nun savunma faaliyetlerini sabote etmesi nedeni ile sınır bölgesindeki Ermenilerin güney bölgelerine sevk edilmeleri ${ }^{72}$, Askeri yönden belli yerlere göçleri kararlaştırılan Ermenilerin sevkleri esnasında vukua gelen suistimalleri Divan-1 Harb'e tevdi etmek üzere oluşan komisyonların harcırahlarımın ödenmesi ${ }^{73}$, Ermeni Katogikosluk ve Ermeni Patrikhanesi Nizamnamesi'nin yeniden düzenlenmesi ${ }^{7}$, Ermeni Patrikliği Nizamnamesi hükmünü ilga eden Ermeni Katogikosluğu ve Patrikliği Nizamnamesi'nin ilgası zımnında kaleme alınan nizamiye layihasının yürürlüğe konulmak üzere arzı ${ }^{75}$ gibi konuları ihtiva etmektedir.

\section{e) Sadaret Belgeleri:}

Mektubî Kalemi Mühimme Kalemi (A.MKT.MHM.); Mektubî Kalemi'yle birlikte ilk yillardan beri devam edegelen ve onun bir şubesi durumunda bulunan kalemdir. Önemli ve âcil olan hususları ayırdedebilmek için gerek evrakta, gerekse defterlerde mühim ve adî ayırımı yapıldığı görülmüștür. $\mathrm{Bu}$ sebeple, mühimme, hafâya ve mahremâne kaydı bulunan Mektubî Kalemi evrakı için ayrı bir fon teşkiline ihtiyaç duyulmuştur. Bu evrak umumiyetle isyan, deprem, sımır meselesi, savaş, kıtlık ve iskân gibi mühim hususları ihtiva etmektedir.

Sadaret fonlarında Ermenilerle ilgili üç bine yakın belge vardır. Bu fonda bulunan belgelerin konuları Hariciye, Dahiliye ve Yildız belgeleriyle büyük oranda benzerlik göstermektedir.

Anadolu'nun bir çok vilayetinde meydana gelen Ermeni ayaklanmalarıyla ilgili ayrıntılar ${ }^{76}$, Ermenilerin İstanbul'da çıkardıkları olaylar ${ }^{77}$, Erme-

${ }^{71}$ BOA., MV.177/74

${ }^{72}$ BOA., MV.198/24

${ }^{73}$ BOA., MV.199/35

${ }^{71}$ BOA., MV.244/22.

${ }^{75}$ BOA., MV.249/217.

77 BOA., A MKT. MHM., 483/64; BOA., A MKT. MHM.,501/24; BOA., A MKT. MHM., 535/25; BOA., A MKT. MHM., 609/13; BOA., A MKT. MHM., 609/14; BOA., A MKT. MHM., 609/15; BOA., A MKT. MHM., 609/16; BOA., A MKT. MHM., 609/30; BOA., A MKT. MHM., 611/11; BOA., A MKT. MHM., 619/8; BOA., A MKT. MHM., 620/17; BOA., A MKT. MHM., 623/1; BOA., A MKT. MHM., 628/1; BOA., A MKT. MHM., 628/3; BOA., A MKT. MHM.,628/42; BOA., A MKT. MHM.,628/48.

${ }^{77}$ BOA., A MKT. MHM., 609/4; BOA., A MKT. MHM. 
niler için umumi af ilani ${ }^{78}$, İngiltere ${ }^{79}$, Fransa $^{80}$, Rusya $^{81}$ ve Amerika ${ }^{82}$ gibi ülkelerin Ermeniler lehine faaliyetleri, Doğu Anadolu'da yapılacak sslahat ${ }^{83}$, Hınçak ve Taşnak komitelerinin faaliyetleri ${ }^{81}$, Amerika'ya Ermeni göçleri ${ }^{85}$, Bulgaristan'da Ermeni faaliyetleri ${ }^{86}$, misyoner faaliyetleri ${ }^{87}$, Rusya'ya firar eden Ermeniler, Ermeniler arasindaki mezhep kavgaları, yabancı basında Ermeniler lehine yapılan propaganda faaliyetleri ${ }^{\mathrm{ks}}$ ana konu başlıklarıdır.

\section{f) Zaptiye Nezareti Belgeleri (ZB.)}

Zaptiye Nezareti'ne ait mevcut arșiv malzemesinin ekserisini, nezarete diğer nezaret, devâir ve vilayetlerden gelip gerekli muameleleri yapılan yazıșmalar ile esas itibariyle bu yazılara verilen cevapları havî Mektubî ve Muhasebe kalemleri müsveddeleri ve Muhasebe Kalemi'nin muamelâtuna ait makbuz, teslim ve tesellüm senetleri gibi evrakın oluşturduğu görülmektedir.

Zaptiye Nezareti fonlarında Ermenilerle ilgili iki bin civarında belge bulunmaktadır.

Ermenilerin gazete çıkarmaları için müsaade talepleri" ${ }^{8 !}$, Ermeni komitecilerinin mektup tercümeleri\%, Ermeni komitelerine mensup olanlar hakkında yapılan sorușturmalar ${ }^{91}$, Meșrutiyet'in ilanından sonra

78 BOA., A MKT. MHM., 539/6; BOA., A MKT. MHM.,539/10; BOA., A MKT. MHM., 539/201; BOA., A MKT. MHM., 538/32; BOA., A MKT. MHM., 539/11.

79 BOA., A MKT. MHM., 716/9; BOA., A MKT. MHM., 752/17; BOA., A MKT. MHM., $749 / 5$

80 BOA., A MKT. MHM., 616/26; BOA., A MKT. MHM., 651/17; BOA., A MKT. MHM.,673/13; BOA., A MKT. MHM., 549/21.

${ }^{81}$ BOA., A MKT. MHM., 549/30; BOA., A MKT. MHM., 550/6; BOA., A MKT. MHM., $625 / 16$.

${ }^{82}$ BOA., A MKT. MHM., 532/38; BOA., A MKT. MHM., 533/2; BOA., A MKT. MHM., $533 / 21$.

${ }^{83}$ BOA., A MKT. MHM., 611/13.

84 BOA., A MKT. MHM., 548/7; BOA., A MKT. MHM., 609/34; BOA., A MKT. MHM., 611/3; BOA., A MKT. MHM., 617/19; BOA., A MKT. MHM., 618/10; BOA., A MKT. MHM., $618 / 11$

85 BOA., A MKT. MHM., 538/13; BOA., A MKT. MHM., 538/26; BOA., A MKT. MHM., $538 / 30$

${ }^{86}$ BOA., A MKT. MHM., 537/28; BOA., A MKT. MHM., 538/19

${ }^{87}$ BOA., A MKT. MHM., 618/43.

${ }^{88}$ BOA., A MKT. MHM., 536/31; BOA., A MKT. MHM., 537/6;

${ }^{89}$ BOA., ZB. 24/28; BOA., ZB.24/68; BOA., ZB. 24/69; BOA., ZB.24/84.

${ }^{90}$ BOA., ZB. $43 / 26$.

91 BOA., ZB. $47 / 7 ; 311 / 8$. 
yurtdıșından gelen Ermenilerin memleketlerine sevkleri ${ }^{92}$, ihtida edenlerle ilgili muameleler ${ }^{13}$, Ermeni Komitelerinin gerekli inzibati tedbirler alınarak olay çıkmasına meydan verilmemesi"', İstanbul'da Ermenilerin çıkardıkları olaylarla ilgili yazışmalar, alınan tedbirler, Anadolu'da meydana gelen isyanlarla ilgili yazıșmalar ve daha bir çok husus bu fonda yer almaktadır.

\section{g) Salname-i Devlet-i Aliye}

Burada Osmanlı Devleti'nin Ermenilere bakış açısını ortaya koymak amacıyla, tehcir öncesi ve sonrasında Osmanlı merkezi yönetiminde üst düzey görevlerde bulunan bazı Ermenilerin isimleri ve görev yaptıkları birimler öncelikli olarak 1297 (1881), 1301 (1885), 1305 (1889) ve 1308 (1892)yıllanı Devlet Salnameleri'ne göre şunlardır:

Mahkeme-i Temyiz Ceza Dairesi azası Karabet Efendi, Hariciye Nezareti Tahrirat-1 Hariciye Katibi Serkis Efendi, Hariciye Nezareti Muhasebecisi Kirkor Efendi, Hariciye Nezareti Tahrirat-1 Hariciye Kalemi Mühimme Müdürü Nişan Efendi, Nafia Dairesi Müsteşarı Odyan Efendi, Nafia Dairesi Tercüme Kalemi Müdürü Kigork Efendi ${ }^{95}$, Hariciye Nezareti Müsteşarı Artin Efendi ${ }^{9 \omega}$, Hariciye Nezareti Tercümanı Mikail Efendi ${ }^{17}$, Adliye Nezareti Müsteşarı Vahan Efendi ${ }^{\prime \prime}$, Encümen-i İntihap Memurin-i Adliye Heyeti Müsteșarı Andon Efendi ${ }^{(9)}$, Hazine-i Hassa Nazırı Agop Paşa ${ }^{100}$, Bab-1 Ali İstișare Odası müșaviri Gabriyel Noradunkyan Efendi ${ }^{101}$, Dersaadet Emniyet Sandığı Müdürü Mığırdıç Efendi ${ }^{102}$, Orman ve Maadin Müdürü Bedros Efendi ${ }^{103}$, Ziraat Müdürü Amasyan Efendi ${ }^{104}$, Divan-1 Muhasebat Reisi Ohannes Efendi ${ }^{105}$.

12 BOA., ZB. 330/112; BOA., ZB. 330/52.

3 BOA., ZB. 395/72.

${ }^{91}$ BOA., ZB. 22/23; BOA., ZB. 333/57; BOA., ZB. 338/64; BOA., ZB. 595/98.

Salname-i Devlet-i Aliyye, Dersaadet 1297.

96 Salname-i Devlet-i Aliyye, Dersaadet 1301; Salname-i Devlet-i Aliyye, Dersaadet 1305; Salname-i Devlet-i Aliyye, Dersaadet 1308.

${ }^{97}$ Salname-i Devlet-i Aliyye, Dersaadet 1301.

98 Salname-i Devlet-i Aliyye. Dersaadet 1301; Salname-i Devlet-i Aliyye, Dersaadet 1305; Salname-i Devlet-i Alyye, Dersaadet 1308.

(n) Salname-i Devlet-i Aliyye, Dersaadet 1301.

100 Salname-i Devlet-i Alyye, Dersaadet 1308.

101 Salname-i Devlet-i Aliyye, Dersaadet 1301.

102 Salname-i Devlet-i Aliyye, Dersaadet 1301.

103 Salname-i Devlet-i Aliyye, Dersaadet 1301; Salname-i Devlet-i Aliyye, Dersaadet 1305; Salname-i Devlet-i Aliyye, Dersaadet 1308.

${ }^{10-1}$ Salname-i Devlet-i Aliyye, Dersaadet 1301.

${ }^{105}$ Salname-i Devlet-i Aliyye, Dersaadet 1301. 
Maliye Nazırı Agob Paşa ${ }^{106}$, Ticaret ve Nafia Nezareti Müsteşarı Horen Efendi $^{107}$, Ticaret ve Nafia Nezareti Tahrirat-1 Ecnebiyye Kalemi Müdürü Melkon Efendi, Ticaret ve Nafia Nezareti Ziraat Müdürü Amasyan Efendi ${ }^{108}$, Sanayii Nefise Mektebi Dahiliye Müdürü Oskan Efendi ${ }^{109}$, Ticaret ve Nafia Nezareti İstatistik Müdürü Amasyan Efendi ${ }^{110}$.

1327 (1911), 1328 (1912) yılları ve 1333-1334 (1917-1918) ylları Devlet salnamelerinde kayıtlı görünen Ermenilerden bazılanı ise:

Hariciye Nezareti Müsteşarlığı'nda Ohannes Kuyumcuyan Efendi, Kalem-i Mahsus Mümeyyizliği'nde Dikran Çayan Bey"11, Hariciye Nezareti İstişare Odası Muavinliği'nde Nişan Civanyan Efendi ${ }^{112}$, Dahiliye Nezareti Sicill-i Ahval İdare-i Umumiyesi Müdürü Agop Hamamcıyan Efendi ${ }^{113}$, İstanbul Polis Müdüriyet-i Umumiyesi Heyet-i Sıhhiye Tabibliği'nde Dikran Efendi ${ }^{114}$, Adliye Nezareti İhsaiyat ve Müdevvenat-1 Kanuniye Müdüriyeti'nde Müdür olarak Serkiz Karakoç Efendi ${ }^{15}$, Hazine-i Hassa-i Şâhâne Müdürlüğüne bağlı Emlâk-1 Hâkâni Muhâsebe Müdüriyeti'nde Müdür olarak Agob Efendi ${ }^{116}$, Maliye Nezareti Müsteşarı Mihran Efendi ${ }^{117}$, Nafia Nazırı olarak Sinabyan Efendi ${ }^{118}$ tehcir öncesi dönemde görev yapan önemli bürokratlardandır.

Tehcir sonrası dönemin devlet kayıtlarına bakıldığı zaman da bir çok önemli görevde Ermenilerin bulundukları görülmektedir. Hazine-i Hassa-i Şahane Müdüriyet-i Umumiyesi Emlak-1 Hakani Muhasebe İdaresi Müdürü Agop Efendi ${ }^{19}$, Daire-i Sadaret Müdevvenat-1 Kanuniye Müdürü Karakoç Serkis Efendi ${ }^{120}$, Adliye ve Mezahib Nezareti Kanunname-i Ticaret Komisyonu Reisi (eski Nafia Nazırı) Hallacyan Efendi, Azası (eski Nafia Nazırı ve

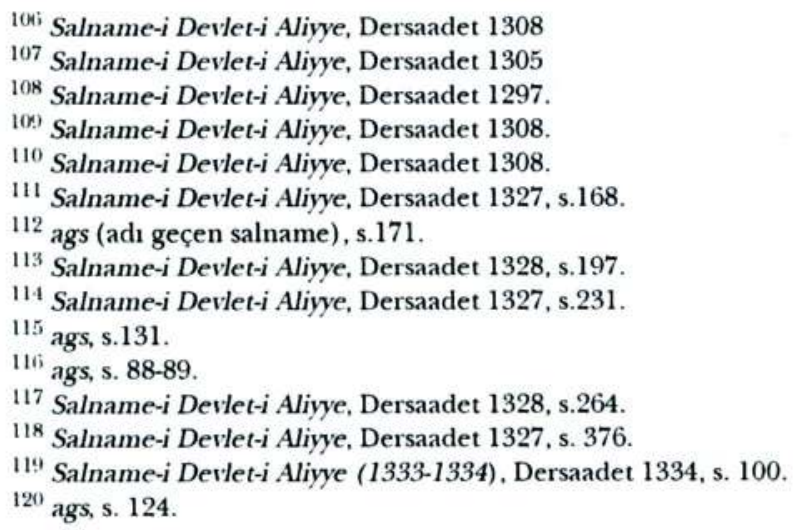


dava vekili) Sinabyan Efendi ${ }^{121}$, Rüsumat Müdüriyet-i Umumiyesi Kontrol Kalemi Müdürü Mihran Efendi ${ }^{122}$, Maliye Nezareti Tercüme Kalemi Müdürü Panosyan Efendi ${ }^{123}$, Ticaret ve Ziraat Nezareti Orman Müdüriyet-i Umumiyesi İhalat Şubesi Müdürü Oseb Ekşiyan ${ }^{124}$, Şura-yı Devlet Tanzimat Dairesi Azası Hrant Asadoryan Efendi ${ }^{125}$, Ziraat Bankası Teftiş Kalemi Mümeyyizi Hrant Efendi ${ }^{126}$, Adliye ve Mezahib Nezareti Mahkeme-i İstinaf Cünha Kısmı azası Artin Musticiyan Efendi ${ }^{127}$, Adliye ve Mezahib Nezareti Beyoğlu Bidayet Mahkemesi Birinci Ceza Dairesi Azası Misak Mıgıryan Efendi ${ }^{128}$ önemli görevlerde bulunan Ermenilerden sadece bir kısmıdır.

\section{h) Takvim-i Vekayi ve Düstur}

Bilindiği gibi Osmanlı devletinin Ermeniler hakkında yayınladığı kanun, nizamname ve talimatlar Takvim-i Vekayi ve Düstur'larda yer almaktadır. Tehcir uygulaması ve sonrasında çıkarılan kanun, nizamname ve talimatlar aşağıda gösterilmektedir:

1 Haziran 1915 yllında çıkarılan "Vakt-i seferde icraat-ı hükûmete karşı gelenler için cihet-i askeriyece ittihaz olunacak tedabir ${ }^{129}$.

10 Kasım 1915'te çıkarılan 13 Eylül 1331 (26 Eylül 1915) tarihli kanun-1 muvakkatin suver-i icraiyesini mübeyyin nizamname ${ }^{130}$.

25 Aralık 1915'te çıkarılan Ahar mahallere nakl olunan eșhasdan istihkak iddiasında bulunanların nazar-1 dikkatine Tasfiye Komisyonlarının kuruluşu ve komisyon merkezlerinin listesi ${ }^{131}$.

26 Aralık 1915'te çıkarılan İstanbul'da Emval-i Metruke Tasfiye Komisyonu'nun faaliyete başlaması hakkında kanun ${ }^{132}$.

\footnotetext{
121 ags, s. 155.

122 ags, s. 262.

123 ags, s. 254.

124 ags, s. 342.

${ }^{125}$ ags, s. 126.

${ }^{126}$ ags, s. 371 .

127 ags, s. 160.

128 ags, s. 165.

12:) Takvim-i Vekayi Nu: 2189

${ }^{130}$ Takvim-i Vekayi Nu: 2343

131 Takvim-i Vekayi Nu: 2388

132 Takvim-i Vekayi Nu: 13
} 
14 Ekim 1916'da çıkarılan Ahar mahallere nakl edilen eşhasın emval ve düyun ve matlubat-1 metrukesine mütedair 17 Zilkade 1333 (26 Eylül 1915) tarihli kanun-1 muvakkatin 2. maddesinin 1. fikrasına müzeyyel ibare hakkında kanun-1 muvakkat ${ }^{133}$.

20 Ekim 1917'de çıkarılan ahar mahallere nakl edilen eșhasın emval ve düyun ve matlubat-1 metrukesine mütedair kanun-1 muvakkatin suver-i icraiyesi hakkındaki 30 Zilhicce 1333 (8 Kasım 1915) tarihli nizamnamenin 3, 5 , 6 ve 8 . maddelerini muaddel mevadd- 1 nizamiye ${ }^{134}$.

5 Kasım 1918'de çıkarılan Vakt-i seferde icraat-ı hükûmete karșı gelenler için cihet-i askeriyece ittihaz olunacak tedabir hakkındaki 13 Recep 1333(27 Mayıs 1915) tarihli kararnamenin reddi hakkında meclis-i mebusan kararnamesi ${ }^{135}$.

18 Kasım 1918'de çıarılan 20 Ramazan 1279 (11 Mart 1863) tarihli Ermeni Patrikliği nizamnamesi hükmünü ilga eden 2 Şevval 1334 ve 19 Temmuz 1332 (2 Ağustos 1916) tarihli Ermeni katogikos ve patrikliği nizamnamesinin ilgasi ${ }^{136}$.

25 Aralık 1918 'de çıkarılan İdare-i örfiye cari olmayan yerlerde tehcir dolayısıyla ika olunan ceraimin merci-i tahkik ve muhakemesi hakkında kararname ${ }^{137}$.

7 Nisan 1919 'da çıkarılan memleketlerine avdet eden mehcurinden 1334 senesi zeytin aşarmm suret-i istifasına dair kararname ${ }^{13 k}$.

12 Ocak $1920^{\prime}$ de çıkarılan ahar mahallere nakl edilmiş olan eşhasın 17 Zilkade 1333 (26 Eylül 1915) tarihli kararname mucebince tasfiyeye tabi tutulan emval hakkunda kararname ${ }^{139}$.

14 Eylül 1922 'de çıkarılan ahar mahallere nakledilmiş eșhasın tasfiyeye tabi emvali hakkında mevcut kararnamenin reddine dair Heyet-i Umumiye karar1 1't.

\footnotetext{
${ }^{133}$ Takvim-i Vekavi Nu: 2672

131 Düstur 2. Tertip Cilt: 9, Sayfa: 759-760

135 Düstur 2. Tertip Cilt: 11, Sayfa: 51

136; Takvim-i Vekayi Nu: 3399

${ }^{137}$ Düstur 2. Tertip Cilt: 11, Sayfa: 81

138 Düstur 2. Tertip Cilt: 11, Sayfa: 196

13:1 Takvim-i Vekayi Nu: 3747

${ }^{110}$ Düstur 3. Tertip, 3. Cilt, s. 127
} 
31 Ekim 1922'de çıkarılan mahal-i ahara nakl edilen eşhasın emval-i metrukesi hakkında 17 Zilkade 1333 (26 Eylül 1915) tarihli kanun-ı muvakkatin suver-i icraiyesine mütedair 26 Teşrin-i Evvel 1332 (5 Kasım 1916) tarihli nizamnamenin bazı mevaddım muadil kararname ${ }^{1: 1}$.

15 Nisan 1923'te çıkarılan ahar mahalere nakl edilen eşhasın emval ve düyun ve matlubat-1 metrukesi hakkındaki 17 Zilkade 1333 ve 13 Eylül 1331 (26 Eylül 1915) tarihli kanun-1 muvakkatin bazı mevaddı ile 20 Nisan 1338 (3 Mayıs 1922) tarihli emval-i metruke kanununu muadil kanun ${ }^{1 / 2}$.

29 Nisan 1923'te çıkanılan 13 Eylül 1331 (26 Eylül 1915) tarihli kanun-1 muvakkat ile işbu kanunun bazı mevaddım muadil 15 Nisan 1339 (28 Nisan 1923) tarihli kanunun suver-i tatbikiyesini mübeyyin talimatname ${ }^{13}$.

\section{Genelkurmay ATASE ve Genelkurmay Denetleme Başkanlığı Arşivi}

Genelkurmay ATASE ve Genelkurmay Denetleme Başkanlığı Arşivi'nde 1853-1856 Kırın Harbi'nden bașlayarak günümüze kadar olan dönemleri kapsayan savaş, harekât, istihbarat ve lojistik destek konularındaki belgelerden meydana gelen arşiv fonları bulunmaktadır. Tasnifi tamamlanarak arașturmacılarm hizmetine sunulan önemli fonlar șunlardır:

Osmanlı-Rus Harbi (Kırım Harbi) (1853-1856); Osmanlı Sırp-Karadağ Harbi (1875-1877), Osmanl1-Rus Harbi (1877-1878), Osmanl-Yunan Harbi (1897), Osmanl-İtalyan ve Balkan Harpleri (1911-1913), Birinci Dünya Harbi (1914-1918), Türk İstiklal Harbi (1919-1922), Atatürk Koleksiyonu ile haritalar ve albümler bulınmaktadır.

Bu arşivde yer alan Birinci Dünya Harbi fonunda genel olarak Ermeni meselesi ve tehcir uygulaması ile ilgili çok sayıda belge bulunmaktadır.

Ermenilerden gönüllü alaylar oluşturulmakta olduğu ve Rus ordusuna katılacakları, Ermeniler tarafundan devletlere verilen muhtura, Amerika'dan Ermenilere gelen paraların dağıtılmasıyla ilgili yazışmalar, Bogos Nubar'ıı kurduğu Ermeni Cemiyeti'nin siyasi faaliyetleri, Üçüncü Ordu Komu-

\footnotetext{
111 Düstur 3. Tertip, 3. Cilt, s. 151, 152

112 Düstur 3. Tertip, 4. Cilt, s. 79-81

113 Düstur 3. Tertip. 4. Cilt, s. 94-100
} 
tam'nm Erzurum ve civarındaki Amerikan Misyonerlerinin Ermenilerle bağlantılar1 ${ }^{144}$.

Boğazlıyan civarındaki Ermeni çetelerinin faaliyetleri, Ermenilerin esliha ve mühimmat fabrikalarına saldıracaklarının istihbar edildiği gerekli tedbirlerin alınmasi; Erzincan ve Erzurum'da Ermeni mezalimi, Ermeni ve Kürt çetelerinin faaliyetleri; Van civarındaki Ermenilerin isyan ettikleri ve Türk köylerini bastıkları; Ermenilerden ele geçirilen bomba ve bomba yapimında kullanılan malzemeler ${ }^{115}$.

Hınçak ve Taşnak komitesine mensup olup, Muzır Ermenilerden olan ve tutuklananlardan Samsun'da olanların isimleri, Dahiliye Nazırı Talat Bey'in asayişin sağlanmasıyla ilgili telgrafi; Ermeni muhacirlerinin yerleştirilmesiyle ilgili yazıșmalar; Hunçak ve Taşnak Komitesi'ne mensup Bafra, Çarșamba ve Ünye kazalarında tevkif edilen Ermenilerin listesi, Ermenilerin bulundukları vilayet ve evliye mıntıkaları dahilinde ne suretle seyahat edebileceklerine dair; Tarsus ve Avanos hattundaki Ermeni efradmdan şüpheli olanlarm öncelikli olarak Musul'a sevkleri, Cebel-i Bereket dahilindeki Ermeni çetelerinin tenkili, Ermenilerin sevk sebepleri ve yerlerinin tayini; Üçüncü ordu mıntıkasındaki Ermenilerden bir kısmmnn Musul vilayetine sevkleri sırasında Van'daki Rus kuvvetleri ve Ermeni çetelerine iltihaklarının meni için 4. Ordu muntıkasına sevklerinin engellenmesi, Musul vilayetinde bulunan yerli ve muhacir Ermenilerin kafile kafile düșman tarafina kaçmakta olduğu hakkında 6. Ordu Kumandamı Ali İhsan Pașa'dan Başkumandanlığa şifre; Ermeni sevkinin durdurulmasına dair Dahiliye Nezareti'nden Başkumandanlığa tezkire; Bazı mahallerde sakin Ermenilerin mahal-i saireye nakl ve sevkleri hakkında Sadaret'ten Harbiye Nezareti'ne tezkire, Dahiliye Nezareti'nin tehcir ve iaşe ile ilgili talimatları ${ }^{1 / 4}$ gibi konularda çok sayıla belge bulunmaktadır.

111 ATASE Arşivi, BDH Koleksiyonu, Klasör 310, Dosya 1260, Fihrist 1; BDH.K. 521. D. 2029, F. 1577:

$115 \mathrm{BDH}, \mathrm{K} .2287$, D. 11 ; F. 3-7, 3-8; 3-9; 4, 4-1; K. 359, K. 1435, F. 3-43, 44; K. 4, D. $234, \mathrm{~K}$. 44, D. 207; K. 341, D. 1006, F. 1-21.

Itii BDH, K. 521. D. 2029, F. 3, 4-4-1; K. 341, D. 1086; F. 1-50; K. 527, D. 2057, F. 15-3, 14-4, $15-5 ; 15-6$; K. 1530 , D. 385, F. 8, 8-1, 8-2; 38, 38-1, 38-2, 38-3, 41; K. 16, D. 5168, F. 20; K. 361, D. 1445 , F. 2-9, 2-10; F. 8, 8-1, 8-2; F. 8-21. F. 12-11, K. 2292, D. 32, F. 1, 1-1, 1-2, 1-3, 1-4, 1-5, 1-6, 1$7,1-8,1-9$. 


\section{Sonuç}

Tarihi yazanın, yapana sadık kalması tarih araştırmaları için büyük önem taşımaktadır. Bu bakımdan, Ermeni konusunda da tarihi delillerden yoksun bir şekilde önyargı ve siyasi bir yaklașım bilime olan saygıyı ortadan kaldıracaktır. Nitekim bazı çevrelerin Ermenilerle ilgili iddiaları tarihi ve bilimsel temellerden ziyade, haturat türü subjektif eser ve değerlendirmelere dayandırılmakta ve tarihi seçici bir şekilde kullanmaktadırlar. Yani tarih, olayları belli bir sebep-sonuç ilişkisi içinde ortaya koyan, kendi içinde tutarlılığı olan bir bütün olmaktan çıkarılmakta, herkesin işlerine gelen argümanları çekip çıkardığı bir bilgi ambarı olarak kullanılarak, tarih tutsak hale getirilmektedir.

Bu sebeple Ermeni sorununun arşivlere dayanılarak objektif bir şekilde değerlendirilmesi amacıyla Türk arşivleri yerli ve yabancı bütün bilim insanlarına açılmış, yapılan mevzuat düzenlemesi ve otomasyon sistemi ile kolay ulaşılabilir bir arşiv haline getirilmiş, bilgiye ve belgeye ulaşımdaki bürokratik engeller ortadan kaldırılmışur. 